\title{
Characterization of Asparagine Deamidation in Immunodominant Myelin Oligodendrocyte Glycoprotein Peptide Potential Immunotherapy for the Treatment of Multiple Sclerosis
}

\author{
Maria-Eleni Androutsou ${ }^{1}$, Agathi Nteli ${ }^{2}$, Areti Gkika ${ }^{2}$, Maria Avloniti ${ }^{3}$, Anastasia Dagkonaki ${ }^{3}$, \\ Lesley Probert ${ }^{3}$, , Theodore Tselios ${ }^{2, *}$ and Simona Golič Grdadolnik ${ }^{4, *(D)}$ \\ 1 Vianex S.A., Tatoiou Str., 18th km Athens-Lamia National Road, 14671 Athens, Greece; \\ androutsoum@vianex.gr \\ 2 Department of Chemistry, University of Patras, 26504 Patras, Greece; anteli@upatras.gr (A.N.); \\ areti220@gmail.com (A.G.) \\ 3 Laboratory of Molecular Genetics, Hellenic Pasteur Institute, 127 Vasilissis Sophias Ave., 11521 Athens, \\ Greece; m.avloniti.17.5@gmail.com (M.A.); anastaciadk16@gmail.com (A.D.); lesley.probert@gmail.com (L.P.) \\ 4 Laboratory for Molecular Structural Dynamics, National Institute of Chemistry, Hajdrihova 19, \\ 1001 Ljubljana, Slovenia \\ * Correspondence: ttselios@upatras.gr (T.T.); simona.grdadolnik@ki.si (S.G.G.); Tel.: +30-26-1099-7905 (T.T.); \\ +38-61-4760-409 (S.G.G.)
}

Received: 7 August 2020; Accepted: 6 October 2020; Published: 13 October 2020

\begin{abstract}
Mannan (polysaccharide) conjugated with a myelin oligodendrocyte glycoprotein (MOG) peptide, namely $(\mathrm{KG})_{5} \mathrm{MOG}_{35-55}$, represents a potent and promising new approach for the immunotherapy of Multiple Sclerosis (MS). The $\mathrm{MOG}_{35-55}$ epitope conjugated with the oxidized form of mannan (poly-mannose) via a $(\mathrm{KG})_{5}$ linker was found to inhibit the symptoms of $\mathrm{MOG}_{35-55}$-induced experimental autoimmune encephalomyelitis (EAE) in mice using prophylactic and therapeutic vaccinated protocols. Deamidation is a common modification in peptide and protein sequences, especially for Gln and Asn residues. In this study, the structural solution motif of deaminated peptides and their functional effects in an animal model for MS were explored. Several peptides based on the $\mathrm{MOG}_{35-55}$ epitope have been synthesized in which the $\mathrm{Asn}^{53}$ was replaced with Ala, Asp, or isoAsp. Our results demonstrate that the synthesized MOG peptides were formed to the deaminated products in basic conditions, and the Asn ${ }^{53}$ was mainly modified to Asp. Moreover, both peptides (wild type and deaminated derivative) conjugated with mannan (from Saccharomyces cerevisiae) independently inhibited the development of neurological symptoms and inflammatory demyelinating spinal cord lesions in $\mathrm{MOG}_{35-55}$-induced EAE. To conclude, mannan conjugated with a deamidated product did not affect the efficacy of the parent peptide.
\end{abstract}

Keywords: asparagine deamidation; nuclear magnetic resonance; myelin oligodentrocyte glycoprotein; experimental autoimmune encephalomyelitis; multiple sclerosis

\section{Introduction}

Peptides and proteins play an important role in the field of medicinal chemistry and biomedical research. In the pharmaceutical industry, peptides are emerging as a novel class of therapeutic agents. To date, about 100 peptides are on the market in the USA, Europe, and Japan, as well as for diagnostics applications [1-3]. Peptides demonstrate significant advantages as potential pharmaceuticals over small molecules due to their high biological activity and high receptor specificity [4]. 
During the design and synthesis of peptides, one has to consider numerous interactions and behaviors of the constituting amino acids. A search of the literature revealed that in many cases, several types of impurities might be encountered in synthetic peptides. Impurities can either originate from raw materials during the manufacturing process or be formed during storage [5]. In many cases, during the characterization of synthetic peptides, detectable byproducts lack one or more amino acid residues in the desired peptide sequence. It was noticed that Met, Trp, and Cys amino acids are sensitive to oxidation. The oxidation of a Cys-containing peptide yields a disulfide bridge to form cystine; Met is converted into a sulfoxide [6]. Both transformations are reversible. Tyr and Trp in peptide sequences should be protected from sunlight, as both amino acids are at risk of photo-oxidation [7]. The rate of racemization in solid-phase peptide synthesis is common and depends on many factors, including the electron-withdrawing effect of the amino acid side chain, the temperature, the reaction solvent, and the coupling reagents [8-11]. Acetylation of amino functions could occur in acidic conditions with the treatment of trifluoroacetic acid. This reaction is reversible in mild alkaline conditions [12]. Other side-reactions in peptide synthesis address the Trp reduction by trialkyl silane and the irreversible alkylation on the Cys side chain functional group during the deprotection step [13].

Deamidation of Gln and Asn presents a frequent modification in peptide and protein sequences. This reaction is favored in neutral and mostly basic solutions. Deamidation of Asn leads to a mixture of L, D-succinimidyl, L, D-aspartyl, and L, D-iso aspartyl with the greater presence of L-iso aspartyl [14]. The new product adds to the mass of intact molecule +0.984 Da the difference between the mass of hydroxyl $(-\mathrm{OH})$ and amine $\left(-\mathrm{NH}_{2}\right)$ functional groups. The intermediate cyclic imide succinimide appears with a different molecular weight, $17-18$ Da less [15,16].

Slight modifications in the sequence can result in drastic changes in the structure and function of peptides. For example, a modified residue such as deaminated Asn could positively or negatively affect the peptide/protein potency, efficacy, and safety [17-21]. Thus, deamidation should be monitored using several analytical techniques such as LC-MS/MS analysis, capillary electrophoresis, and NMR [22].

The presented study involves the investigation of deaminated products in combination with experimental autoimmune encephalomyelitis (EAE, animal model of multiple sclerosis (MS)), the evaluation of 35-55 myelin oligodendrocyte glycoprotein $\left(\mathrm{MOG}_{35-55}\right)$ epitope that contains the $-\mathrm{Asn}^{53}-\mathrm{Gly}^{54}$ - sequence. MOG is a glycoprotein located on the external surface of the myelin sheath [23-25]. The 35-55 epitope of rat MOG (MOG ${ }_{35-55}$ : H-Met ${ }^{35}$-Glu-Val-Gly-Trp-Tyr-Arg-SerPro-Phe-Ser-Arg-Val-Val-His-Leu-Tyr-Arg-Asn $\left.{ }^{53}-\mathrm{Gly}_{-}-\mathrm{Lys}^{55}-\mathrm{OH}\right)$ induces chronic EAE in mice of the C57BL/6 strain and is widely used for in vivo biological evaluation and immunological studies relevant to MS treatment [26-29]. The immunogenic $\mathrm{MOG}_{35-55}$ epitope conjugated to polysaccharide (mannan) via the $(\mathrm{KG})_{5}$ bridge at $N$ terminal protected mice against EAE when administered in prophylactic and therapeutic protocols [30-37]. Combinations of different peptides from myelin proteins (including MOG peptides) have been used in clinical studies against MS [38]. Moreover, MOG $_{35-55}$ is one of the immunodominant epitopes that, conjugated to peripheral blood monocytes, resulted in a decrease of antigen-specific T cell responses in MS patients [38]. The structure of peptides based on the $\mathrm{Asn}^{53}$ transformation of synthesized $\mathrm{MOG}_{35-55}$ peptides has been explored. Model peptides with mutations of Asn with Ala, Asp, or isoAsp were synthesized and analyzed with 2D NMR spectroscopy in neutral and basic aqueous solutions. The comparison of chemical shifts and NMR signal patterns reveals the $\mathrm{Asn}^{53}$ deamidation to Asp in basic conditions while it is not revealed in neutral solution. Furthermore, the modified peptide containing Asp at position 53 showed similar biological activity compared to that of the wild type peptide against EAE when the peptides are conjugated to mannan polysaccharide.

\section{Results and Discussion}

\subsection{Design and Synthesis of Peptides Based on the Immunodominant $M O G_{35-55}$ Epitope}

$\mathrm{MOG}_{35-55}$ is the main immunodominant epitope of MOG protein and is of great interest in our research regarding the peptide-based EAE treatment. This epitope conjugated with the oxidized 
form of mannan (poly-mannose) via a $(\mathrm{KG})_{5}$ linker was found to inhibit the EAE symptoms in mice using prophylactic and therapeutic vaccinated protocols [30-34]. The conjugation reaction of $(\mathrm{KG})_{5} \mathrm{MOG}_{35-55}$ peptide analog with oxidized mannan was performed in bicarbonate buffer solution, $\mathrm{pH}$ 9.0. In the basic conditions of conjugation reaction, the deamidation of $\mathrm{Asn}^{53}$ may occur. Model peptides were designed and synthesized (Pep 1-Pep 4), as shown in Table 1, to investigate the possibility of the formation of deaminated products during conjugation reaction. The obtained results lead to further investigation, and the $(\mathrm{KG})_{5} \mathrm{MOG}_{35-55}$ peptides with Asn or Asp or isoAsp, respectively (Pep 5-Pep 7; human sequence) at position 53 were synthesized. A combination of reverse-phase high-performance liquid chromatography (RP-HPLC) and NMR were used to confirm the existence of deaminated products. Furthermore, it was interesting to examine how the chemically modified peptides would affect the immunological properties of the native peptide. Therefore, the rat sequence of $(\mathrm{KG})_{5} \mathrm{MOG}_{35-55}\left(\mathrm{Ser}^{42}\right)$ (Pep 8) and the deaminated derivative containing Asp at position $53(\mathrm{KG})_{5} \mathrm{MOG}_{35-55}\left(\mathrm{Ser}^{42}, \mathrm{Asp}^{53}\right.$ ) (Pep 9) were synthesized and conjugated with the oxidized form of mannan (Con-Pep 8 and Con-Pep 9). Both conjugates were evaluated in vivo in C57BL/6 mice using the EAE animal model of MS.

Table 1. Sequence of studied peptides.

\begin{tabular}{|c|c|c|}
\hline Peptide & Peptide Sequence & Abbreviation \\
\hline Pep 1 & $\begin{array}{c}\text { H-Arg }{ }^{41} \text {-Pro-Pro-Phe-Ser-Arg-Val-Val-His-Leu-Tyr-Arg- } \\
\text { Asn }{ }^{53} \text {-Gly-Lys }{ }^{55} \text {-OH }\end{array}$ & $\mathrm{MOG}_{41-55}$ \\
\hline Pep 2 & $\begin{array}{l}\text { H-Arg }{ }^{41} \text {-Pro-Pro-Phe-Ser-Arg-Val-Val-His-Leu-Tyr-Arg- } \\
\text { Ala }^{53} \text {-Gly-Lys }{ }^{55} \text {-OH }\end{array}$ & $\mathrm{MOG}_{41-55}\left(\mathrm{Ala}^{53}\right)$ \\
\hline Pep 3 & $\begin{array}{c}\text { H-Arg }{ }^{41} \text {-Pro-Pro-Phe-Ser-Arg-Val-Val-His-Leu-Tyr-Arg- } \\
\text { Asp }\end{array}$ & $\mathrm{MOG}_{41-55}\left(\mathrm{Asp}^{53}\right)$ \\
\hline Pep 4 & $\begin{array}{l}\text { H-Arg }{ }^{41} \text {-Pro-Pro-Phe-Ser-Arg-Val-Val-His-Leu-Tyr-Arg- } \\
\text { isoAsp }{ }^{53} \text {-Gly-Lys }{ }^{55} \text {-OH }\end{array}$ & $\mathrm{MOG}_{41-55}\left(\mathrm{isoAsp}^{53}\right)$ \\
\hline Pep 5 & $\begin{array}{l}\text { H-Lys-Gly-Lys-Gly-Lys-Gly-Lys-Gly-Lys-Gly-Met }{ }^{35} \text {-Glu- } \\
\text { Val-Gly-Trp-Tyr-Arg-Pro-Pro-Phe-Ser-Arg-Val-Val-His- } \\
\text { Leu-Tyr-Arg-Asn }{ }^{53} \text {-Gly-Lys }{ }^{55} \text {-OH }\end{array}$ & $(\mathrm{KG})_{5} \mathrm{MOG}_{35-55}$ \\
\hline Pep 6 & $\begin{array}{l}\text { H-Lys-Gly-Lys-Gly-Lys-Gly-Lys-Gly-Lys-Gly-Met }{ }^{35} \text {-Glu- } \\
\text { Val-Gly-Trp-Tyr-Arg-Pro-Pro-Phe-Ser-Arg-Val-Val-His- } \\
\text { Leu-Tyr-Arg-Asp } \\
\text { 53-Gly-Lys }{ }^{55} \text {-OH }\end{array}$ & $(\mathrm{KG})_{5} \mathrm{MOG}_{35-55}\left(\mathrm{Asp}^{53}\right)$ \\
\hline Pep 7 & $\begin{array}{l}\text { H-Lys-Gly-Lys-Gly-Lys-Gly-Lys-Gly-Lys-Gly-Met }{ }^{35} \text {-Glu- } \\
\text { Val-Gly-Trp-Tyr-Arg-Pro-Pro-Phe-Ser-Arg-Val-Val-His- } \\
\text { Leu-Tyr-Arg-isoAsp } \\
\text { 53-Gly-Lys s5-OH }\end{array}$ & $(\mathrm{KG})_{5} \mathrm{MOG}_{35-55}\left(\mathrm{isoAsp}^{53}\right)$ \\
\hline Pep 8 & $\begin{array}{l}\text { H-Lys-Gly-Lys-Gly-Lys-Gly-Lys-Gly-Lys-Gly-Met }{ }^{35} \text {-Glu- } \\
\text { Val-Gly-Trp-Tyr-Arg-Ser }{ }^{42} \text {-Pro-Phe-Ser-Arg-Val-Val-His- } \\
\text { Leu-Tyr-Arg-Asnn }{ }^{53} \text {-Gly-Lys }{ }^{55} \text {-OH }\end{array}$ & $(\mathrm{KG})_{5} \mathrm{MOG}_{35-55}\left(\mathrm{Ser}^{42}\right)$ \\
\hline Pep 9 & $\begin{array}{l}\text { H-Lys-Gly-Lys-Gly-Lys-Gly-Lys-Gly-Lys-Gly-Met }{ }^{35} \text {-Glu- } \\
\text { Val-Gly-Trp-Tyr-Arg-Ser } \\
\text { Leu-Tyr-Arg-Aspo-Phe-Ser-Arg-Val-Gal-His- } \\
\text {-Gly-Lys }{ }^{55} \text {-OH }\end{array}$ & $(\mathrm{KG})_{5} \mathrm{MOG}_{35-55}\left(\mathrm{Ser}^{42}, \mathrm{Asp}^{53}\right)$ \\
\hline Con-Pep 8 & 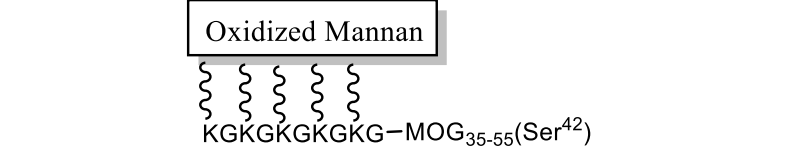 & $\mathrm{OM}-(\mathrm{KG})_{5} \mathrm{MOG}_{35-55}\left(\mathrm{Ser}^{42}\right)$ \\
\hline Con-Pep 9 & 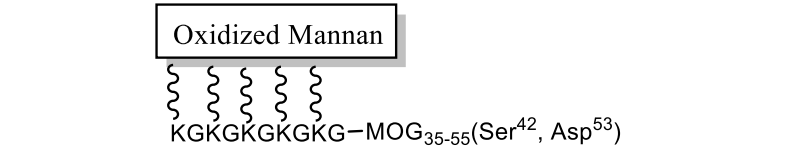 & $\mathrm{OM}-(\mathrm{KG})_{5} \mathrm{MOG}_{35-55}\left(\mathrm{Ser}^{42}, \mathrm{Asp}^{53}\right)$ \\
\hline
\end{tabular}


The Pep 1-Pep 9 peptides (Table 1) were synthesized by solid-phase peptide synthesis (SPPS) in combination with the Fmoc/tBu methodology and using acid-labile 2-chlorotrityl chloride (CLTR-Cl) resin and $N^{\alpha}$-Fmoc (9-fluorenylmethyloxycarboxyl)-protected amino acids, as previously described and presented in Scheme 1 [39-46]. The first $N^{\alpha}$-Fmoc protected amino acid was esterified to the CLTR-Cl resin in the presence of diisopropylethylamine (DIPEA) and followed by Fmoc deprotection. The peptide bonds were created using 1-Hydroxybenzotriazole (HOBt) and $N, N^{\prime}$-Diisopropylcarbodiimide (DIC) as coupling reagents [39-46]. The final deprotection of each peptide was achieved using trifluoroacetic acid (TFA) in dichloromethane (DCM) in the presence of scavengers (Scheme 1). The synthesized peptides were further purified and identified using semi-preparative RP-HPLC and electron spray ionization mass spectrometry (ESI-MS), respectively. The purity of peptides was more than $95 \%$, as determined by analytical RP-HPLC.<smiles>Oc1ccc(C(Cl)(c2ccccc2)c2ccccc2Cl)cc1</smiles>

1. Fmoc-Lys(Boc)-OH, DIPEA

2. $25 \%$ piperidine/DMF

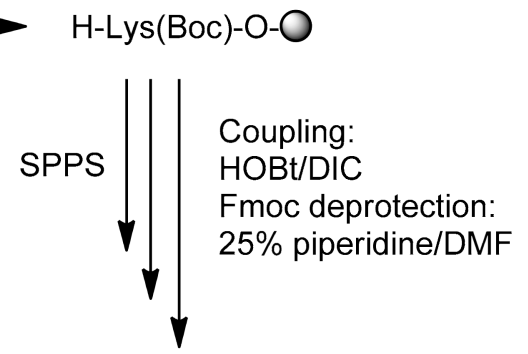

H-Arg(Pbf)-Pro-Pro-Phe-Ser(tBu)-Arg(Pbf)-Val-Val-His(Trt)-Leu-Tyr(tBu)-Arg(Pbf)-X-Gly-Lys(Boc)-O-O

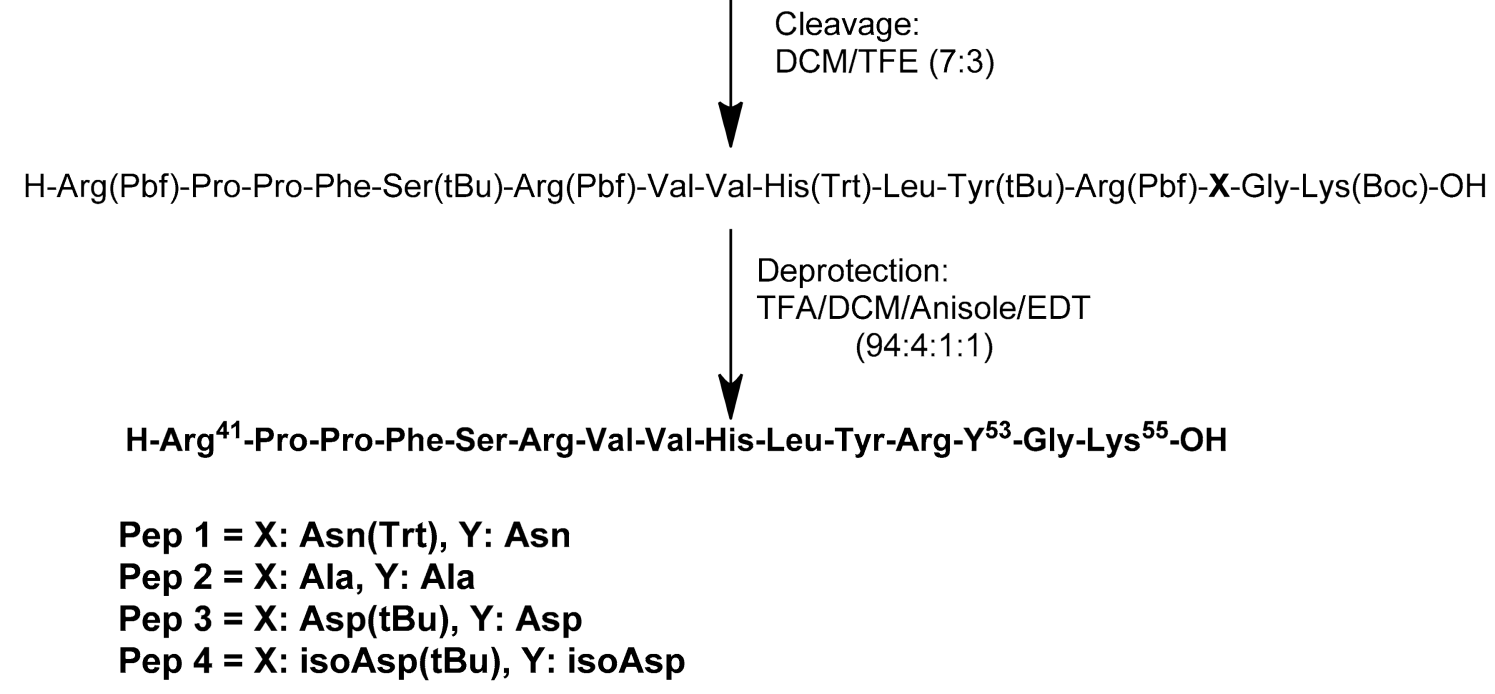

Scheme 1. Representative SPPS of model peptides (Pep 1-Pep 4). The same synthetic procedure was followed for the synthesis of Pep 5-Pep 9 peptides.

\subsection{HPLC Analysis}

The HPLC analysis of synthesized peptides was achieved using the analytical HPLC system (1260 Infinity, Quaternary Pump VL Agilent, Waldbronn, Germany) equipped with the Purospher RP-18 column $(5 \mu \mathrm{m}$, Hibar $100 \times 4.6 \mathrm{~mm}$, Darmstadt, Germany), followed by UV detection at $214.4 \mathrm{~nm}$ and $254 \mathrm{~nm}$. Separation was achieved by gradient elution from $18 \%$ acetonitrile (AcN) to $40 \%$ AcN over $30 \mathrm{~min}$ at a flow rate of $1 \mathrm{~mL} / \mathrm{min}$. The analysis demonstrated that the peptide with Asn residue at position 53 has been degraded and provided two new peaks at the right of the main peak in HPLC chromatogram after dilution in bicarbonate solution $\mathrm{pH} 9.0$ (Figure 1 and Figure S1). The relative 
retention time of the $(\mathrm{KG})_{5} \mathrm{MOG}_{35-55}\left(\mathrm{Ser}^{42}\right)$ deaminated analog, based on HPLC chromatogram (Figure 1), is 1.06, and this was further investigated during the present study.

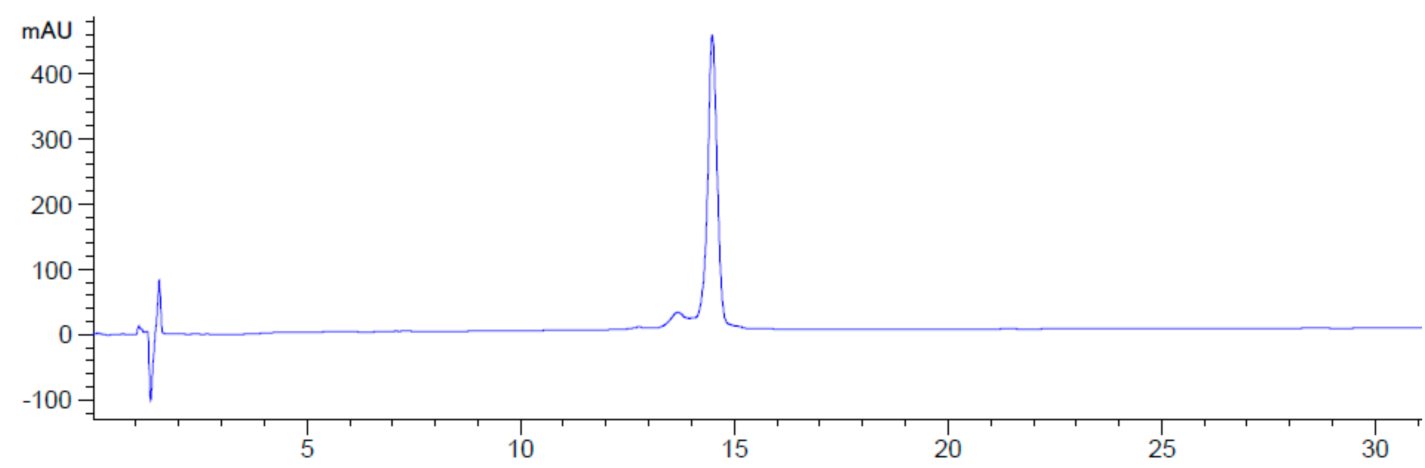

(A)

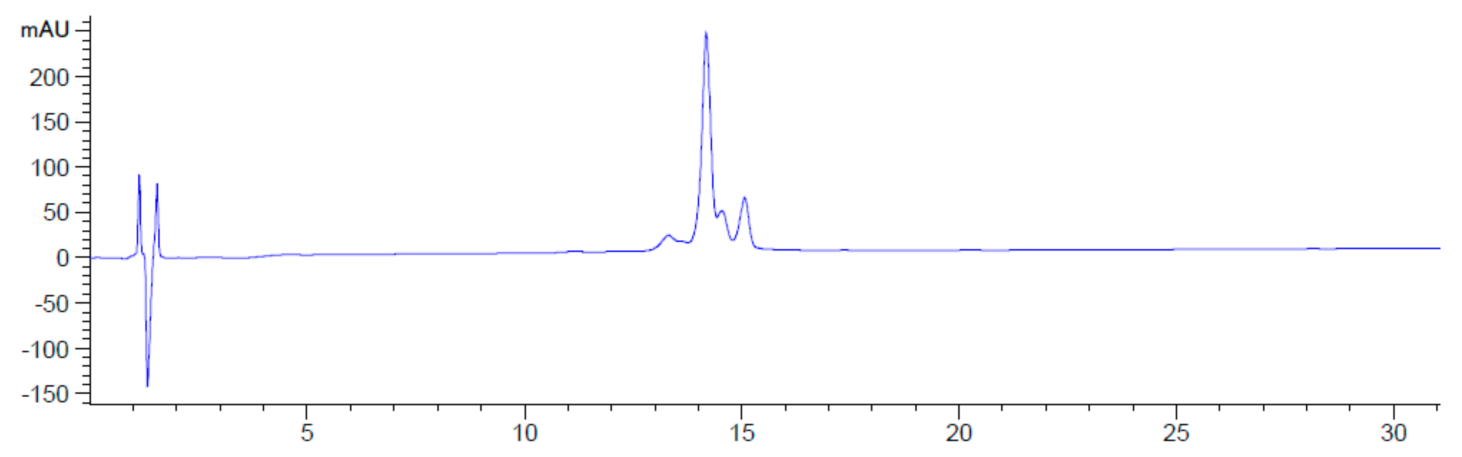

(B)

Figure 1. RP-HPLC chromatogram of (KG) ${ }_{5} \mathrm{MOG}_{35-55}\left(\mathrm{Ser}^{42}\right)$ (Pep 8) at $214.4 \mathrm{~nm}$ and $48 \mathrm{~h}$ after dilution; (A) dissolved in water, $(\mathbf{B})$ dissolved in bicarbonate buffer $\mathrm{pH}$ 9.0. The deaminated product was revealed as a new peak to the right of the main peak.

The possibility of deamidation of Asn was apparent since the literature has addressed studies related to this formation [14-22]. Several peptides were synthesized based on 35-55 epitope of MOG (Pep 1, Pep 5, and Pep 8); with substitution of Asn residue with Ala (Pep 2), Asp (Pep 3, Pep 6, and Pep 9), and isoAsp (Pep 4, Pep 7), and they were analyzed by HPLC and ESI-MS (Figure 1 and Figures S1-S15). It was observed that the byproduct is revealed only in Pep 1, Pep 5, and Pep 8 peptides, containing $\mathrm{Asn}^{53}$, in basic conditions (carbonate buffer $\mathrm{pH}$ 9.0), and it was not detected in the other synthesized peptides with Ala, Asp, or isoAsp substitutions at the same position (Figures S1-S15). The deamidation formation is initiated upon dilution of the peptides in bicarbonate buffer solution and stabilizes after one day. The identified retention times in HPLC chromatograms of produced byproducts in basic conditions of peptides Pep 1, Pep 5, and Pep 8 matched the retention times of the synthesized peptides Pep 3, Pep 6, and Pep 9. This observation supports that Pep 1, Pep 5, and Pep 8 containing the Asn residue at position 53 undergo deamidation and semi-covert to the peptides Pep 3 , Pep 6, and Pep 9.

\subsection{NMR Analysis}

The NMR chemical shift analysis of peptides 1-7 was performed to elucidate the nature of modification observed at HPLC analysis in basic conditions for peptides containing Asn at position 53. As the NMR chemical shifts are very sensitive to changes in the local chemical environment, the modifications related to $\mathrm{Asn}^{53}$ could also result in chemical shifts of neighboring residues. Indeed, expansions of the Total Correlated Spectroscopy (TOCSY) spectra recorded in bicarbonate buffer $\mathrm{pH} 9.0$, which contain well separated ${ }^{1} \mathrm{H} \alpha-\beta$ cross-peaks of residues 51 and 53 and $\alpha-\delta$ cross peaks of residue 52 
of all investigated peptides, came out as the most demonstrative to elucidate the modification process (Figure 2). The positions and appearance of these cross-peaks critically depend on the modification of $\mathrm{Asn}^{53}$ and the presence of produced byproducts. The chemical shifts of $\alpha, \beta$ and $\delta$ protons of residues 51,52 and 53 for peptides 1 to 7 , which are relevant for the position of representative cross-peaks in TOCSY, are given in Table S1.

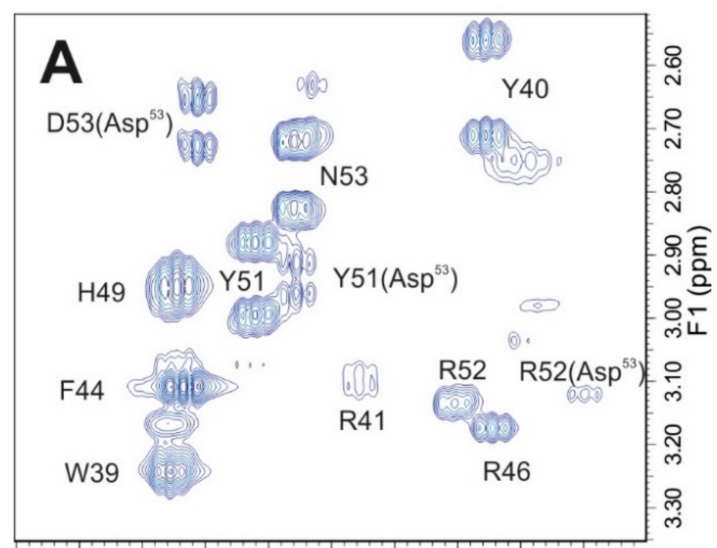

$\begin{array}{lllllllll}4.65 & 4.60 & 4.55 & 4.50 & 4.45 & 4.40 & 4.35 & 4.30 & 4.25\end{array}$

$$
\mathrm{F} 2 \text { (ppm) }
$$
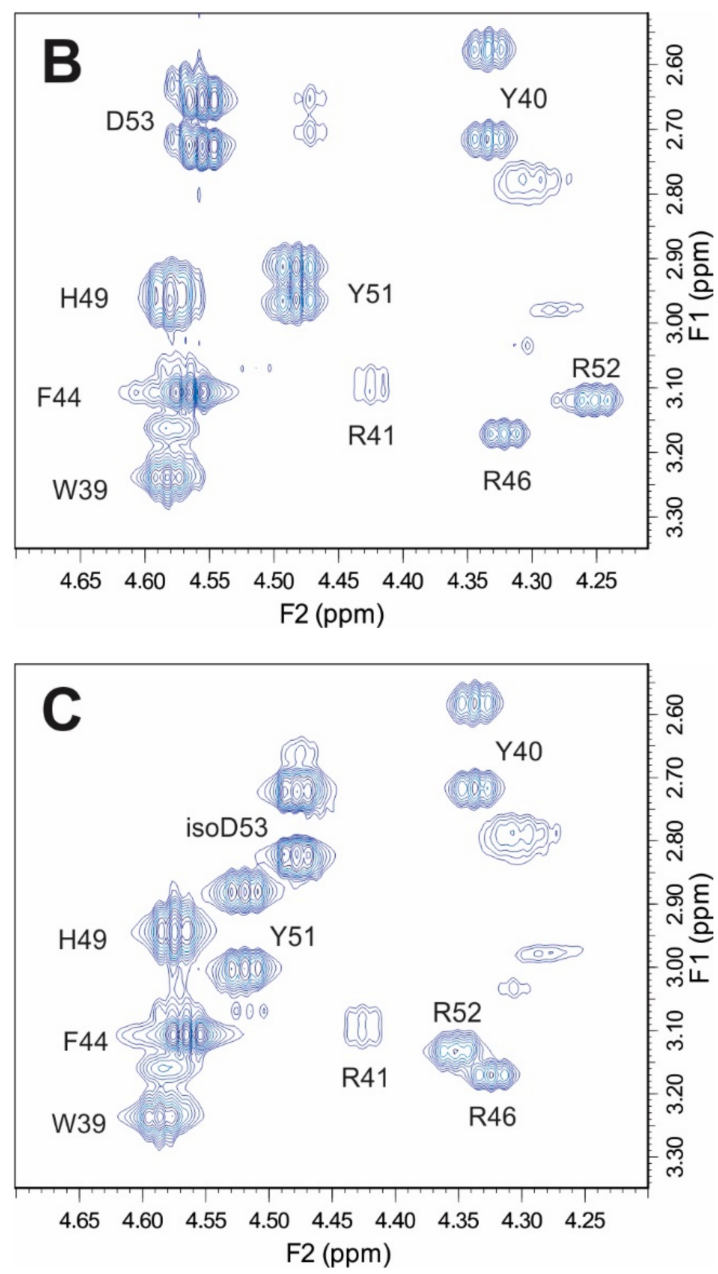

Figure 2. Expanded regions of Total Correlated Spectroscopy (TOCSY) spectra of: (A) (KG) MOG $_{35-55}$ (Pep 5), (B) (KG) MOG $_{35-55}\left(\mathrm{Asp}^{53}\right)$ (Pep 6) and (C) (KG) ${ }_{5} \mathrm{MOG}_{35-55}\left(\right.$ isoAsp $\left.^{53}\right)$ (Pep 7) recorded in bicarbonate buffer, $\mathrm{pH} 9.0$. 
In the expanded TOCSY spectrum of (KG) ${ }_{5} \mathrm{MOG}_{35-55}$ (Pep 5), two sets of signals were observed for residues 51,52 and 53 (Figure 2A), indicating a modification in this peptide region. Only one set of signals was observed for the residues remote from position 53. In the spectra of $(\mathrm{KG})_{5} \mathrm{MOG}_{35-55}\left(\mathrm{Asp}^{53}\right)$ (Pep 6) and $(\mathrm{KG})_{5} \mathrm{MOG}_{35-55}\left(\right.$ isoAsp ${ }^{53}$ ) (Pep 7), only one set of signals appeared for all residues (Figure 2B,C), indicating that these two peptides were not prone to any modification process. The comparison of cross-peak patterns in expanded TOCSY spectra of Pep 5, Pep 6, and Pep7 clearly demonstrate the type of modification at $\mathrm{Asn}^{53}$. Namely, the positions of $\alpha-\beta$ cross-peaks of $\mathrm{Asn}^{53} / \mathrm{Asp}^{53}$ and $\mathrm{Tyr}^{51}$ and $\alpha-\delta$ cross-peaks of Arg ${ }^{52}$ considerably differed between Pep 6 and Pep 7 (Figure 2B, C). The positions of the additional weaker set of signals observed in expanded TOCSY region of Pep 5 (Figure 2A) were the same as the positions of the $\alpha-\beta$ cross-peaks of $A p^{53}$ and $\mathrm{Tyr}^{51}$, and the $\alpha-\delta$ cross-peak of $\mathrm{Arg}^{52}$ of Pep 6 (Figure 2B). These observations clearly indicate a partial deamidation of $\mathrm{Asn}^{53}$ in Pep 5 to $\mathrm{Asp}^{53}$. The position of cross-peaks of the residues remote from position 53 was the same for all three peptides Pep 5, Pep 6, and Pep 7.

In the TOCSY region of the byproduct isolated via semi-preparative HPLC from (KG) ${ }_{5} \mathrm{MOG}_{35-55}$ (Pep 5) in bicarbonate buffer $\mathrm{pH}$ 9.0, two sets of signals appeared at the same positions as observed for Pep 5 (Table S1, Figure S16). However, the intensity ratio between the two sets of signals was different. In contrast to observations in the TOCSY spectra of Pep 5 (Figure 2A), the signals in the TOCSY spectra of byproducts corresponding to $(\mathrm{KG})_{5} \mathrm{MOG}_{35-55}\left(\mathrm{Asp}^{53}\right)$ (Pep 6) were stronger, and the signals corresponding to Pep 5 were weaker. That means that the byproduct of Pep 5 is Pep 6, while the presence of weaker signals of Pep 5 in the spectra of byproduct was the consequence of the not totally successful separation of byproduct from Pep 5. Namely, a small amount of Pep 5 was co-eluted with its byproduct (Pep 6).

Additional confirmation for the partial deamidation of $\mathrm{Asn}^{53}$ was obtained by the comparison of cross-peak patterns in the corresponding expanded TOCSY spectra of the shorter model peptides MOG $_{41-55}$, containing Asn (Pep 1), Ala (Pep2), Asp (Pep 3), and isoAsp (Pep 4) at position 53, as recorded in bicarbonate buffer at pH 9.0 (Figure S17). Similarly to (KG) ${ }_{5} \mathrm{MOG}_{35-55}$, two sets of signals were observed only for residues 51, 52, and 53 of $\mathrm{MOG}_{41-55}$ (Pep 1) containing Asn at position 53 (Figure S17A). Only one set of signals was present in the spectra of Pep 2, Pep 3, and Pep 4 (Figure S17D, $B$ and $C$, respectively). Moreover, the positions of the additional weaker set of cross-peaks of Pep 1 (Figure S17A) were the same as the positions of the $\alpha-\beta$ cross-peaks of $\operatorname{Asp}^{53}$ and Tyr ${ }^{51}$ and the $\alpha-\delta$ cross peak of Arg ${ }^{52}$ of Pep 3 (Figure S17B), indicating partial deamidation of $\mathrm{Asn}^{53}$ to $\mathrm{Asp}^{53}$ in Pep 1.

Comparison of expanded TOCSY spectra of peptides 1 to 7 recorded in bicarbonate buffer $\mathrm{pH}$ 9.0, which are presented in Figure 2 and Figure S17, clearly demonstrated a modification of Pep 1 and Pep 5 due to partial deamidation of the $\mathrm{Asn}^{53}$ to $\mathrm{Asp}^{53}$. The peptides having Asp, isoAsp, or Ala at position 53 were stable.

\subsection{In Vivo Evaluation of Con-Pep 8 and Con-Pep 9 Conjugated to Mannan}

Con-Pep 8 conjugated with the oxidized form of mannan strongly protected C57BL/6 mice against MOG-induced Experimental Autoimmune Encephalomyelitis (EAE) in prophylactic and therapeutic protocols [31]. Moreover, Con-Pep 8 strongly protected transgenic mice expressing the human major histocompatibility complex class II (MHC II) MS candidate susceptibility genes DRA*0101 and DRB1*1501 and lacking all murine MHC II molecules (DR2b.Ab ${ }^{\circ}$ mice) against MOG-EAE with prophylactic or therapeutic applications and therapeutic administration of Con-Pep 8 in mice with ongoing MOG-EAE reduced spinal cord EAE lesions, inflammatory infiltrates, microglial activation, demyelination, and neuronal damage in DR2b. $\mathrm{Ab}^{\circ}$ mice [47].

Administration of Con-Pep 8 [OM-(KG) $\left.{ }_{5} \mathrm{MOG}_{35-55}\left(\mathrm{Ser}^{42}\right)\right]$ or Con-Pep 9 [OM-(KG) ${ }_{5} \mathrm{MOG}_{35-55}$ $\left.\left(\mathrm{Ser}^{42}, \mathrm{Asp}^{53}\right)\right]$, conjugated to mannan in its oxidized form, in a prophylactic (vaccination) protocol both protected mice against the clinical and neuropathological symptoms of MOG-EAE.

To investigate the effect of Pep 9 on the development of MOG-EAE, we delivered Con-Pep 9 or, as a positive control, Con-Pep 8 to C57BL/6 mice in a prophylactic vaccine protocol prior to the induction of 
EAE by immunization with MOG emulsified in CFA and administration of Bordetella pertussis toxin (MOG/CFA/PTx). As described previously, three intradermal (i.d.) injections of Con-Pep 8 in dilute soluble form and spaced at 15-day intervals prior to EAE induction protected mice against the clinical symptoms of EAE [31]. We show here that vaccination with Con-Pep 9 also strongly protected mice against the development of clinical EAE, to an equal extent as Pep 8, compared to vehicle-treated controls (Figure 3, top).

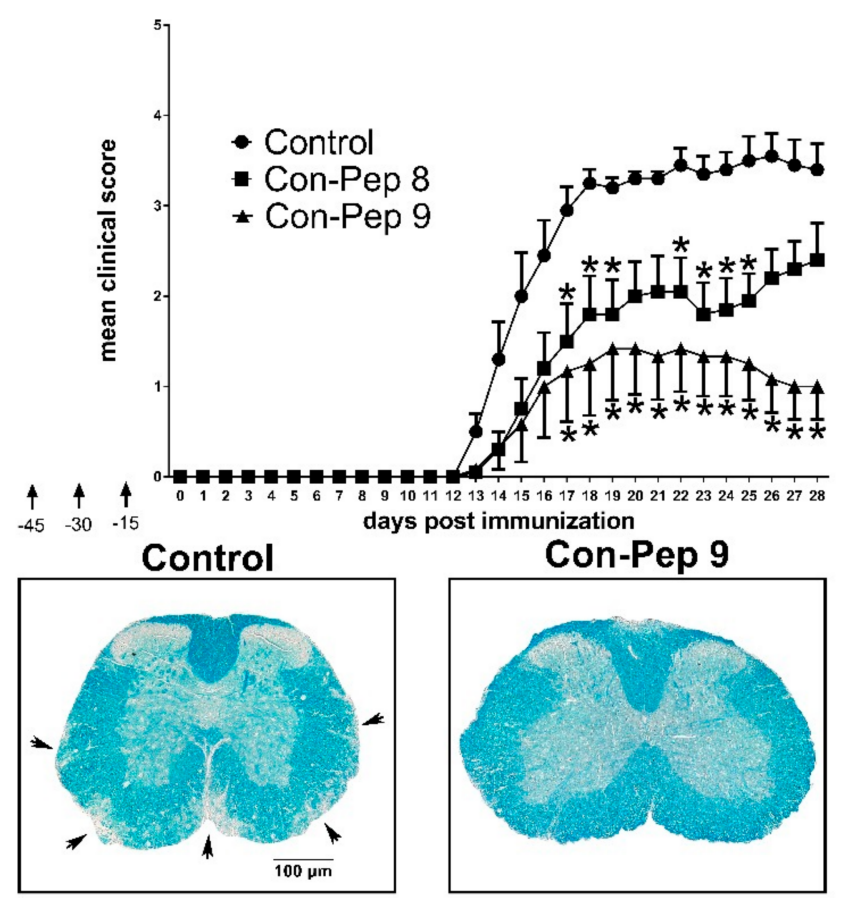

Figure 3. Administration of Con-Pep 8 and Con-Pep 9, conjugated to mannan in its oxidized form, in a prophylactic (vaccination) protocol attenuates the development of MOG-induced experimental autoimmune encephalomyelitis (EAE) in C57BL/6 mice. Top: Mean clinical scores of MOG-EAE in groups of mice vaccinated intradermally (i.d.) with dilute soluble Con-Pep 8, Con-Pep 9 or carbonate buffer $\mathrm{pH} 9.0$ (disease control) at the indicated time points (arrows), prior to the induction of EAE by immunization with MOG/CFA/PTx ( $n=10$ for Con-Pep 8 and control groups, $n=6$ for Con-Pep 9 group). Bottom: MOG-EAE vehicle control mice induces hallmark demyelinating lesions, as seen by Luxol Fast blue staining of spinal cord sections taken from mice sacrificed on day 28 post-immunization for EAE (left panel, arrows). Vaccination with either Con-Pep 8 (data not shown) or Con-Pep 9 prevented the development of spinal cord demyelination (right panel). Representative sections from three animals per group are shown. Statistical significance after comparisons between Con-Pep 8 and 9 treated with control groups of mice by 2 -way ANOVA followed by Bonferroni post-hoc tests is shown $\left({ }^{*} p \leq 0.05\right)$.

To determine whether amelioration of the clinical symptoms of MOG-EAE by Con-Pep 9 was associated with less severe neuropathology, mice from the different groups were sacrificed 28 days after EAE induction for neuropathological analysis of spinal cord tissues. Vehicle-treated control mice showed extensive demyelination of the spinal cord white matter characteristic of this model (Figure 3, bottom left panel). As described previously [31], vaccination of mice with Con-Pep 8 protected them against the neuropathological changes of MOG-EAE (data not shown). Here we show that vaccination of mice with Con-Pep 9 also protected against the development of neuropathological changes, with Con-Pep 9-vaccinated mice showing little or no demyelination in the spinal cord (Figure 3, bottom right panel).

These results show that the administration of Con-Pep 9 as a prophylactic vaccine in mice inhibited the clinical and neuropathological features of MOG-EAE to an equal extent as Con-Pep 8. 


\section{Materials and Methods}

\subsection{Synthesis}

All commercially available solvents and reagents were HPLC grade, purchased from Merck (Darmstadt, Germany), Sigma-Aldrich (Schnelldorf, Germany), Fluka (Buchs, Switzerland), and Across (Geel, Belgium), and they were used without further purification. HPLC grade water was obtained from distilled water passed through a Milli-Q water purification system (Millipore Ltd., Bedford, MA, USA). CLTR-Cl resin (1\% DVB, 200-400 mesh), Fmoc-protected-amino acids and piperidine were purchased from Chemical and Biopharmaceutical Laboratories of Patras, Patras, Greece. The stated resin loading capacity was determined spectrophotometrically using a UV/Visible Spectrophotometer Varian Cary 4000. ESI-MS spectra were acquired using a Waters Micromass ZQ Electrospray Platform coupled to a MassLynx 4.1 data acquisition system (Manchester, UK). HPLC chromatograms were acquired using a 1260 Infinity, Quaternary Pump VL Agilent, (Waldbronn, Germany). The ESI-MS analysis was performed using the ion spray source in positive ion mode with the following settings: (i) capillary voltage: $3.5 \mathrm{kV}$; (ii) cone voltage: $30 \mathrm{~V}$; (iii) source temperature: $80 \mathrm{oC}$; (iv) desolvation temperature: $300 \mathrm{oC}$; (v) desolvation gas: $300 \mathrm{~L} / \mathrm{h}$; (vi) cone gas: $50 \mathrm{~L} / \mathrm{h}$.

\section{Peptide Synthesis}

The studied peptides (Table 1) were successfully synthesized using the solid-phase peptide synthesis (SPPS) and Fmoc/tBu methodology on CLTR-Cl resin [39-46]. The first $N^{a}$-Fmoc protected amino acid, Fmoc-Lys(Boc)-OH, was esterified to the resin in the presence of DIPEA (4.5 equivalent) in DCM for $1.5 \mathrm{~h}$ at room temperature (RT). The remaining active site of the resin was capped using a mixture of dichloromethane (DCM) / Methanol (MeOH) / DIPEA $(85 / 10 / 5 ; v / v / v)$ at RT. The resin was washed with $\mathrm{N}, \mathrm{N}$-dimethylformamide (DMF, three times $\times 5 \mathrm{~mL}$ ) and isopropanol (i-PrOH; three times $\times 5 \mathrm{~mL}$ ) and dried overnight under vacuum. For each peptide, $1 \mathrm{~g}$ CLTR-Cl resin was loaded with Fmoc-Lys(Boc)-OH (1.5 mmol), and the $N^{a}$-Fmoc group was removed with $25 \%$ piperidine in DMF ( $v / v)$ (Scheme 1). The second amino acid, Fmoc-Gly-OH, was added $(2.5 \mathrm{mmol})$ in the presence of $N, N^{\prime}$-diisopropylcarbodiimide (DIC; $2.75 \mathrm{mmol}$ ) and 1-hydroxybenzotriazole (HOBt; $3.75 \mathrm{mmol}$ ) in $\mathrm{N}, \mathrm{N}$-dimethylacetamide (DMAC) for $4 \mathrm{~h}$, followed by Fmoc deprotection with piperidine solution; three times with $25 \%$ piperidine in DMF (v/v) for $5 \mathrm{~min}, 15 \mathrm{~min}$ and $10 \mathrm{~min}$ respectively The coupling and deprotection cycles were repeated for all the other remaining amino acids (Scheme 1). The coupling reaction and Fmoc deprotection were demonstrated by Kaiser test and thin-layer chromatography (TLC; eluent system: $\mathrm{AcN} / \mathrm{H}_{2} \mathrm{O}: 5 / 1$ or $\left.2 / 1 ; v / v\right)$. Then, each protected peptide was cleaved from the resin by treatment with the cleaved solution comprised of DCM/trifluoroethanol (TFE) (7/3) for $1.5 \mathrm{~h}$ at RT, to afford the crude side chain protected peptides. The final deprotection of the peptide was accomplished using a TFA/DCM/Anisole/Ethanodithiol (EDT) $(94 / 4 / 1 / 1 ; v / v / v / v)$ solution for $5 \mathrm{~h}$ at RT.

The purification of each peptide was carried out on a semi-preparative reverse-phase high-performance liquid chromatography (RP-HPLC) using a Nucleosil RP-C18 column (7 $\mu \mathrm{m}$, $250 \times 4 \mathrm{~mm}$, Macherey-Nagel, Duren, Germany). The separation was achieved by gradient elution from $10 \%$ AcN to $60 \%$ AcN over $45 \mathrm{~min}$ at a flow rate of $3 \mathrm{~mL} / \mathrm{min}$. The HPLC solvents for the analytical and semi-preparative HPLC analysis were: $\mathrm{H}_{2} \mathrm{O}$ with $0.08 \%$ TFA, AcN with $0.08 \%$ TFA. The final products were identified using ESI-MS and NMR spectroscopy. The purity of the synthesized peptides was determined by analytical HPLC using a Purospher RP-18 column $(5 \mu \mathrm{m}$, Hibar $100 \times 4.6 \mathrm{~mm}$, Darmstadt, Germany) followed by UV detection at $214.4 \mathrm{~nm}$. Separation was achieved by gradient elution from $18 \%$ AcN to $40 \%$ AcN over $30 \mathrm{~min}$ at flow rate of $1 \mathrm{~mL} / \mathrm{min}$.

The Pep 8 and Pep 9 peptides, based on the rat/mouse sequence of MOG, were conjugated with the oxidized form of mannan (poly-mannose) to Con-Pep 8 [OM-(KG) $\left.{ }_{5} \mathrm{MOG}_{35-55}\left(\mathrm{Ser}^{42}\right)\right]$ and Con-Pep $9\left[\mathrm{OM}-(\mathrm{KG})_{5} \mathrm{MOG}_{35-55}\left(\mathrm{Ser}^{42}, \mathrm{Asp}^{53}\right)\right]$ respectively as previously described $[31,33,34]$, and they were used in the EAE animal model of MS, for further in vivo evaluation. 


\subsection{NMR Spectroscopy}

The high-resolution NMR spectra were recorded on Agilent $600 \mathrm{MHz}$ and Varian DirectDrive $800 \mathrm{MHz}$ spectrometers (Agilent Technologies Inc., Santa Clara, CA 95051, USA) at 298 K. Cryogenic triple-resonance NMR probes were used. Ultra-precision $5 \mathrm{~mm}$ NMR tubes from Wilmad $\AA$ were used containing peptides in a $0.7 \mathrm{~mL}$ aqueous solution of bicarbonate buffer ( $\mathrm{pH} 9.0)$. The $0.1 \mathrm{M}$ bicarbonate buffer solution ( $\mathrm{pH}$ 9.0) was created using sodium bicarbonate and sodium carbonate solutions as follows: Solution A: $0.210 \mathrm{~g} \mathrm{Na}_{2} \mathrm{CO}_{3}$ were dissolved in $10 \mathrm{~mL} \mathrm{D}_{2} \mathrm{O}$; Solution B: $0.168 \mathrm{~g} \mathrm{NaHCO}$ were dissolved in $10 \mathrm{~mL} \mathrm{D}_{2} \mathrm{O} .0 .8 \mathrm{~mL}$ of solution (A) was added to $9.6 \mathrm{ml}$ of solution (B), and the mixture was diluted to the final volume of $50 \mathrm{~mL}$ with the addition of $\mathrm{D}_{2} \mathrm{O}$. $\mathrm{pH}$ was measured with the use of a HANNA pH meter. (Calibration of $\mathrm{pH}$ meter was achieved with the use of calibration solutions, $\mathrm{pH} 4.0$ and $\mathrm{pH} 7.0$, as reported in the instruction manual).

The concentration of peptides was $1.2 \mathrm{mM}$. Water was purified with Milli-Q Water Purification System. $\mathrm{D}_{2} \mathrm{O}$ ("100\%") was purchased from Cambridge Isotope Laboratories. DSS- $d_{6}(0.1 \mathrm{mM})$ purchased from Sigma-Aldrich was used as an internal standard.

The proton chemical shifts of peptides 1-7 were assigned using 2D homonuclear proton experiments (Double Quantum-Filtered Correlated Spectroscopy (DQF-COSY), TOCSY, Nuclear Overhauser Effect Correlation Spectroscopy (NOESY), and Rotating-Frame Nuclear Overhauser Effect Correlation Spectroscopy (ROESY)) in combination with the $2 \mathrm{D}^{1} \mathrm{H}-{ }^{13} \mathrm{C}$ Heteronuclear Single Quantum Coherence (HSQC) experiment.

The 2D homonuclear proton spectra were acquired on a Varian DirectDrive $800 \mathrm{MHz}$ spectrometer with a spectral width of $8478 \mathrm{~Hz}, 4096$ data points in $\mathrm{t}_{2}, 4-32$ scans, 512 complex points in $\mathrm{t}_{1}$, and a relaxation delay of $1.5 \mathrm{~s}$. The mixing time in TOSCY was $60 \mathrm{~ms}$. The mixing times in NOESY and ROESY were $150 \mathrm{~ms}$ and $300 \mathrm{~ms}$.

The ${ }^{1} \mathrm{H}-{ }^{13} \mathrm{C}$ HSQC was recorded on an Agilent $600 \mathrm{MHz}$ spectrometer with ${ }^{1} \mathrm{H}$ spectral width of $6345 \mathrm{~Hz},{ }^{13} \mathrm{C}$ spectral width of $9498 \mathrm{~Hz}, 1024$ data points in $t_{2}, 160$ scans, 128 complex points in $\mathrm{t}_{1}$, and a relaxation delay of $1.5 \mathrm{~s}$.

All data were collected in phase-sensitive mode using pulse sequences and phase-cycling routines provided in Varian/Agilent libraries of pulse programs. In the DQF-COSY and ${ }^{1} \mathrm{H}_{-}{ }^{13} \mathrm{C}$ HSQC experiments, gradients were used for the coherence selection. The WATERGATE pulse block was used for water suppression in DQF-COSY. The residual water signal in TOCSY, NOESY, and ROESY was suppressed using excitation sculpting, and adiabatic pulses were applied for suppression of zero quantum artifacts during mixing time.

Spectra were processed and analyzed with the Felix 2007 software package (Felix NMR Inc., San Diego, CA, USA). The spectra were zero-filled twice and apodized with a squared sine-bell function shifted by $\pi / 2$ in both dimensions. In the ${ }^{13} \mathrm{C}$ dimension, a linear prediction was used.

\subsection{EAE Evaluation}

\subsubsection{Mice}

Female C57BL/6 mice aged 24 weeks were used for the prophylactic administration of peptide conjugates. Mice were bred and maintained under specific pathogen-free conditions in the experimental animal unit of the Hellenic Pasteur Institute. All animal experiments complied with ARRIVE guidelines and were carried out in accordance with the local Ethical Committee guidelines on the use of experimental animals at the Hellenic Pasteur Institute, were approved by the national authorities and conformed to EU Directive 2010/63/EU for animal experiments. Animal experiments were performed under license number 2580/29-05-2018, entitled "Induction of experimental autoimmune encephalomyelitis (EAE) for the study of immune tolerance induced by mannan-conjugated peptides". Issued 31-05-2018 to L.P. by the Hellenic Republic Region of Attica Agricultural Economy, Veterinary and Fisheries. 


\subsubsection{Administration of Peptides to Mice}

In a prophylactic vaccination protocol, groups of adult female C57BL/6 mice (24 week-old) were injected intradermally (i.d.) on the flanks with $100 \mu \mathrm{l}$ carbonate buffer $\mathrm{pH} 9.0$ containing Con-Pep 9 (conjugated with mannan) $(n=6)$ or Con-Pep 8 (conjugated with mannan) $(n=10)$, which has been described previously [31]; $30 \mu \mathrm{g}$ peptide (Pep 8 or Pep 9) equivalent/injection, $700 \mu \mathrm{g}$ mannan equivalent/injection. Three consecutive injections were performed at 15 -day intervals. Control mice were injected with carbonate buffer alone $(n=10)$. Immunization for the induction of EAE was performed 15 days after the last i.d. injection.

\subsubsection{EAE Induction}

EAE was induced in vaccinated female C57BL/6 mice by subcutaneous (s.c.) tail-base injection of $38 \mu \mathrm{g}$ of rat $\mathrm{MOG}_{35-55}\left(\mathrm{Ser}^{42}\right.$ ) (MOG) in $100 \mu \mathrm{L}$ saline emulsified in an equal volume of complete Freund's adjuvant (CFA), 15 days after the third vaccination injection. CFA was supplemented with $400 \mu \mathrm{g} /$ injection of H37Ra Mycobacterium tuberculosis (Difco). Mice also received intraperitoneal (i.p.) injections of $200 \mathrm{ng}$ of Bordetella pertussis toxin (PTx) (Sigma-Aldrich) at the time of immunization and $48 \mathrm{~h}$ later. Mice were monitored daily for the clinical signs of EAE according to the following scores: zero, normal; one, limp tail; two, hind limb weakness; three, hind limb paralysis; four, forelimb paralysis; five, moribund or dead ( 0.5 graduations represent intermediate scores). Mice with a score above four were euthanized and given a clinical score five for the remaining days of the experiment. All mice were allowed free access to food and water throughout the experiment.

\section{Conclusions}

In the present study, the deamidation of 35-55 Myelin Oligodendrocyte Glycoprotein ( $\left.\mathrm{MOG}_{35-55}\right)$ epitope that contains the $-\mathrm{Asn}^{53}-\mathrm{Gly}^{54}$ - sequence was investigated via HPLC, NMR, and biological studies. The 35-55 epitope of rat MOG protein induces chronic EAE in mice of the C57BL/6 strain and is widely used as an animal model for MS for in vivo biological evaluation and immunological studies of novel therapeutics [48]. Moreover, the immunogenic (KG) ${ }_{5} \mathrm{MOG}_{35-55}$ epitope, including the $(\mathrm{KG})_{5}$ bridge in the $\mathrm{N}$-terminal, conjugated to polysaccharide (mannan) via Schiff base, protected mice against EAE in prophylactic and therapeutic protocols [31,47]. Thus, the synthesized Pep 5 conjugated to mannan represents a potent and promising potential new therapeutic approach for the treatment of MS [31,34,36,47]. In addition to the investigation of correspondence, the unmodified form of human $(\mathrm{KG})_{5} \mathrm{MOG}_{35-55}$ peptide, model peptides were synthesized based on the $\mathrm{MOG}_{41-55}$ epitope with modifications at position 53 (Pep 2-4) and studied to determine whether the deamidation reaction happens and to identify deaminated products. Furthermore, it was crucial to investigate the potency of these products and demonstrate how their presence affects the efficiency.

Deamidation may occur via several pathways, as well as peptide dilution in basic conditions. The conjugation reaction between $(\mathrm{KG})_{5} \mathrm{MOG}_{35-55}$ peptide with mannan occurs in basic condition ( $\mathrm{pH}$ 9.0); thus, the deamidation reaction is an unavoidable consequence (Scheme 2). Therefore, the investigation of the immunological properties of the chemically modified peptides and the demonstration of biological action of the modified form of peptide is of great importance, since the deamidation process is associated with the maintenance of action. 


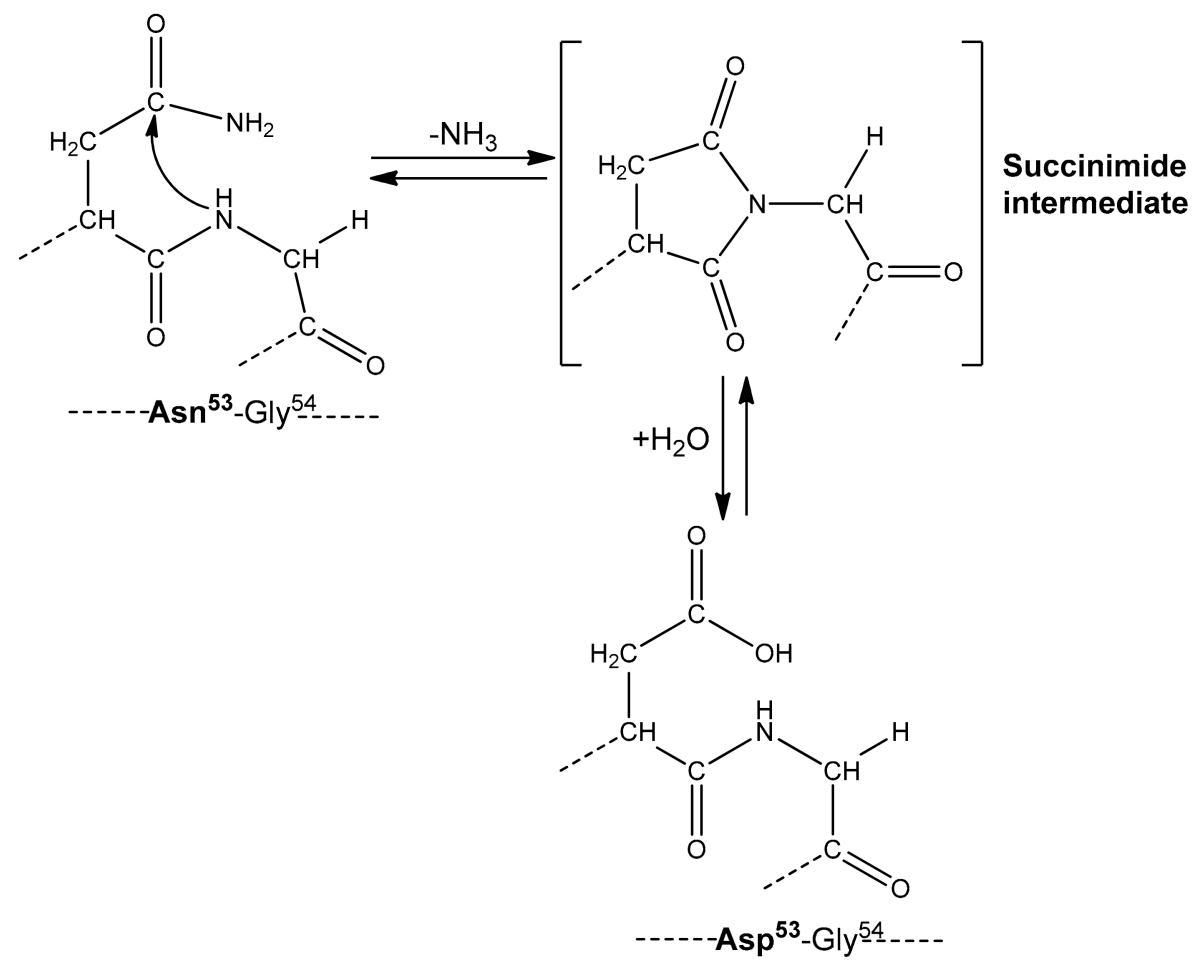

Scheme 2. The main deamidation product of $-\mathrm{Asn}^{53}-\mathrm{Gly}^{54}$ - sequence in MOG peptides under basic conditions.

Our HPLC findings showed the presence of a new product when the peptide (with the -Asn ${ }^{53}-\mathrm{Gly}^{54}$ sequence) was dissolved in bicarbonate buffer solution, $\mathrm{pH}$ 9.0. Twenty-four hours after the dilution, the percentage of formation was almost stabilized and remained about $16 \%$ of the total. The estimated deamidation degree remained constant after three days when the analysis was repeated. The revealed new products were isolated from the mixture via HPLC and analyzed by NMR. The main NMR observations clearly indicated a partial deamidation of $\mathrm{Asn}^{53}$ in (KG) ${ }_{5} \mathrm{MOG}_{35-55}$ peptide (Pep 5) to $\mathrm{Asp}^{53}$. The effect of chemically modified peptides conjugated to the oxidized form of mannan (Con-Pep 8 and Con-Pep 9) was evaluated in vivo in C57BL/6 mice using the EAE animal model of MS. The deaminated derivative containing Asp at position 53 showed similar immunological activity with the native peptide. This evidence suggests that the deaminated product did not affect the biological action of the native peptide and its efficacy while tested in the animal model for the treatment of MS.

Supplementary Materials: Supplementary materials can be found at http://www.mdpi.com/1422-0067/21/20/ 7566/s1. Figure S1: RP-HPLC chromatogram of Pep $1\left(\mathrm{MOG}_{41-55}\right)$ at $214.4 \mathrm{~nm}$, at time zero and $48 \mathrm{~h}$ after dilution; (A) dissolved in water, (B) dissolved in bicarbonate buffer $\mathrm{pH} 9.0 ; \mathrm{t}_{\mathrm{R}}$ (main product): $7.47 \mathrm{~min}(83.1 \%$ ) and $t_{\mathrm{R} \text { (byproduct) }}$ : $8.27 \mathrm{~min}(13.9 \%)$, Figure S2: ESI-MS spectra of Pep 1 ( $\left.\mathrm{MOG}_{41-55}\right)$ dissolved in bicarbonate buffer, $\mathrm{pH}$ 9.0; of main product (A) and byproduct (B); MW theoretical (main product): $1826.12 \mathrm{Da}$, Figure S3: RP-HPLC chromatogram of Pep 2 [MOG $\left._{41-55}\left(\mathrm{Ala}^{53}\right)\right]$ at $214.4 \mathrm{~nm}$, at time zero and $48 \mathrm{~h}$ after dilution; (A) dissolved in water, (B) dissolved in bicarbonate buffer $\mathrm{pH} 9.0 ; \mathrm{t}_{\mathrm{R} \text { (main product) }} 8.45 \min (100 \%)$ and $\mathrm{t}_{\mathrm{R} \text { (byproduct) }}$ : do not observed, Figure S4: ESI-MS spectra of Pep 2 [MOG $\left.\mathrm{MO}_{45}\left(\mathrm{Ala}^{53}\right)\right]$; MW theoretical (main product): $1783.11 \mathrm{Da}$, Figure S5: RP-HPLC chromatogram of Pep 3 [MOG $\left.\mathrm{MO}_{4-55}\left(\mathrm{Asp}^{53}\right)\right]$ at $214.4 \mathrm{~nm}$, at time zero and $48 \mathrm{~h}$ after dilution; (A) dissolved in water, (B) dissolved in bicarbonate buffer $\mathrm{pH} 9.0 ; \mathrm{t}_{\mathrm{R}}$ (main product): $8.3 \mathrm{~min}(100 \%)$ and

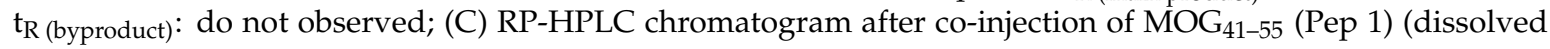
in bicarbonate buffer) and $\mathrm{MOG}_{41-55}\left(\mathrm{Asp}^{53}\right.$ ) (Pep 3) (dissolved in water) at $214.4 \mathrm{~nm}$, Figure S6: ESI-MS spectra of Pep 3 [MOG ${ }_{41-55}\left(\mathrm{Asp}^{53}\right)$ ]; MW theoretical (main product): 1827.12 Da, Figure S7: RP-HPLC chromatogram of Pep 4 [MOG $_{41-55}\left(\right.$ isoAsp $\left.\left.{ }^{53}\right)\right]$ at $214.4 \mathrm{~nm}$, dissolved in water; $t_{\mathrm{R}}$ (main product): $7.6 \mathrm{~min}(100 \%)$, Figure S8: ESI-MS spectra of Pep 4 [MOG $41-55$ (isoAsp ${ }^{53}$ )]; MW theoretical (main product): 1827.12 Da, Figure S9: RP-HPLC chromatogram of Pep $5\left[(\mathrm{KG})_{5} \mathrm{MOG}_{35-55}\right]$ at $214.4 \mathrm{~nm}$, at time zero and $48 \mathrm{~h}$ after dilution; (A) dissolved in water, $(\mathrm{B})$ dissolved in bicarbonate buffer $\mathrm{pH} 9.0 ; \mathrm{t}_{\mathrm{R} \text { (main product) }}: 13.3 \mathrm{~min}\left(88.6 \%\right.$ ) and $\mathrm{t}_{\mathrm{R} \text { (byproduct) }}$ : $13.9 \mathrm{~min}$ $(11.4 \%)$, Figure S10: ESI-MS spectra of Pep $5\left[(\mathrm{KG})_{5} \mathrm{MOG}_{35-55}\right]$ dissolved in bicarbonate buffer, $\mathrm{pH} 9.0$; of main 
product (A) and byproduct (B). MW theoretical (main product): $3518.1 \mathrm{Da}$, Figure S11: RP-HPLC chromatogram of Pep $6\left[(\mathrm{KG})_{5} \mathrm{MOG}_{35-55}\left(\mathrm{Asp}^{53}\right)\right]$ at $214.4 \mathrm{~nm}$, at $48 \mathrm{~h}$ after dilution; (A) dissolved in water, (B) dissolved in bicarbonate

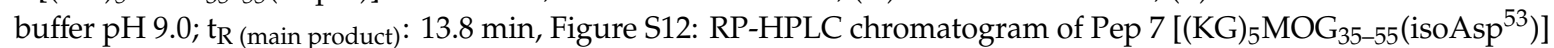
at $214.4 \mathrm{~nm}$, at $48 \mathrm{~h}$ after dilution; (A) dissolved in water, (B) dissolved in bicarbonate buffer $\mathrm{pH} 9.0$; $\mathrm{t}_{\mathrm{R}}$ (main product): $13.3 \mathrm{~min}$, Figure S13: RP-HPLC chromatogram of co-injection [(KG) $\left.{ }_{5} \mathrm{MOG}_{35-55}\left(\mathrm{Asn}^{53}\right)-(\mathrm{KG})_{5} \mathrm{MOG}_{35-55}\left(\mathrm{Asp}^{53}\right)\right]$ at $214.4 \mathrm{~nm}$, at $48 \mathrm{~h}$ after dilution in bicarbonate buffer $\mathrm{pH} 9.0 ; \mathrm{t}_{\mathrm{R}(\text { pep 5) }}: 13.3 \mathrm{~min}, \mathrm{t}_{\mathrm{R}}($ pep 6) $: 13.9$ min, Figure S14: RP-HPLC chromatogram of Pep $8\left[(\mathrm{KG})_{5} \mathrm{MOG}_{35-55}\left(\mathrm{Ser}^{42}\right)\right]$ at $214.4 \mathrm{~nm}$, at time zero after dilution; (A) dissolved in water, (B) dissolved in bicarbonate buffer pH 9.0, Figure S15: ESI-MS spectra of Pep 8 [(KG) $\left.{ }_{5} \mathrm{MOG}_{35-55}\left(\mathrm{Ser}^{42}\right)\right]$ dissolved in bicarbonate buffer, $\mathrm{pH}$ 9.0; of main product (A) and byproduct (B); $\mathrm{MW}$ theoretical (main product): 3508.07 $\mathrm{Da} ; \mathrm{MW}$ theoretical (by product): $3509.06 \mathrm{Da}$, Figure S16: Expanded regions of TOCSY spectra of: (A) (KG) MOG $_{35-55}$ (Pep 5) and (B) isolated byproduct, after semipreparative-HPLC purification, (KG) ${ }_{5} \mathrm{MOG}_{35-55}\left(\mathrm{Asp}^{53}\right)\left(\mathrm{Pep}^{6}\right)$ of $(\mathrm{KG})_{5} \mathrm{MOG}_{35-55}$ (Pep 5) recorded in bicarbonate buffer, $\mathrm{pH}$ 9.0, Figure S17: Expanded regions of TOCSY spectra of: (A) $\mathrm{MOG}_{41-55}$ (Pep 1), (B) $\mathrm{MOG}_{41-55}\left(\mathrm{Asp}^{53}\right.$ ) (Pep 3), (C) $\mathrm{MOG}_{41-55}\left(\right.$ isoAsp ${ }^{53}$ ) (Pep 4) and (D) $\mathrm{MOG}_{41-55}\left(\mathrm{Ala}^{53}\right)$ (Pep 2) recorded in bicarbonate buffer, pH 9.0, Table S1: Chemical shifts in ppm of $\alpha, \beta$ protons of residues 51 and 53 and $\alpha, \delta$ protons of residue 52 for peptides 1 to 7 in bicarbonate buffer ( $\mathrm{pH} 9.0)$ referenced according to DSS- $d_{6}$. These chemical shifts define the position of representative cross-peaks in expanded TOCSY spectra (Figure 2, Figures S16 and S17) relevant for the explanation of degradation of peptides containing Asn at position 53.

Author Contributions: All authors contributed equally. M.-E.A., A.N. and A.G. carried out the synthesis and HPLC analysis of MOG peptides; L.P. designed and analyzed the EAE experiments; M.A. and A.D. carried out the EAE experiments; T.T. designed the MOG peptides and analyzed the HPLC chromatograms; S.G.G. designed and studied the NMR experiments; All authors analyzed the data; T.T. and S.G.G. wrote the paper together with all co-authors. All authors have read and agreed to the published version of the manuscript.

Funding: This research was co-financed by the European Union and Greek national funds through the Operational Program Competitiveness, Entrepreneurship, and Innovation, under the call RESEARCH—CREATE-INNOVATE (project code: T1EDK-01859). NMR studies were supported by the Slovenian Research Agency (Grants No. P1-0010 and J1-8145).

Acknowledgments: AmbioPharm in USA for observations during early stability studies and pharmaceutical company Vianex SA in Greece for their continuous support for Multiple Sclerosis research studies. We recorded NMR spectra on NMR spectrometers of Slovenian NMR Centre at National Institute of Chemistry.

Conflicts of Interest: The authors declare no conflict of interest. The funders had no role in the design of the study; in the collection, analyses, or interpretation of data; in the writing of the manuscript, or in the decision to publish the results.

\section{Abbreviations}

$\begin{array}{ll}\text { MOG } & \text { Myelin Oligodendrocyte Glycoprotein } \\ \text { MS } & \text { Multiple Sclerosis } \\ \text { EAE } & \text { Experimental Autoimmune Encephalomyelitis } \\ \text { SPPS } & \text { Solid Phase Peptide Synthesis } \\ \text { RP-HPLC } & \text { Reverse Phase-High Performance Liquid Chromatography } \\ \text { ESI-MS } & \text { Electron Spray Ionization-Mass Spectrometry } \\ \text { DQF-COSY } & \text { Double Quantum-Filtered Correlated Spectroscopy } \\ \text { TOCSY } & \text { Total Correlated Spectroscopy } \\ \text { NOESY } & \text { Nuclear Overhauser Effect Correlation Spectroscopy } \\ \text { ROESY } & \text { Rotating-Frame Nuclear Overhauser Effect Correlation Spectroscopy } \\ \text { HSQC } & \text { Heteronuclear Single Quantum Coherence }\end{array}$

\section{References}

1. Kaspar, A.A.; Reichert, J.M. Future directions for peptide therapeutics. Drug. Discov. Today 2013, 18, 807-817. [CrossRef]

2. Lau, L.J.; Dunn, K.M. Therapeutic peptides: Historical perspectives, current development trends, and future directions. Bioorg. Med. Chem. 2017, 26, 2700-2707. [CrossRef]

3. Fosgerau, K.; Hoffmann, T. Peptide therapeutics: Current status and future directions. Drug. Discov. Today 2014, 20, 122-128. [CrossRef] [PubMed]

4. Vlieghe, P.; Lisowski, V.; Martinez, J.; Khrestchatisky, M. Synthetic therapeutic peptides: Science and market. Drug. Discov. Today 2010, 15, 40-56. [CrossRef] [PubMed] 
5. Currier, J.; Galley, L.; Wenschuh, H.; Morafo, V.; Ratto-Kim, S.; Gray, C.; Maboko, L.; Hoelscher, M.; Marovich, M.; Cox, J. Peptide impurities in commercial synthetic peptides and their implications for vaccine trial assessment. Clin. Vac. Immunol. 2008, 15, 267-276. [CrossRef] [PubMed]

6. Vogt, W. Oxidation of methionyl residues in proteins: Tools, targets, and reversal. Free Radic. Biol. Med. 1995, 18, 93-105. [CrossRef]

7. Posadaz, A.; Biasutti, A.; Casale, C.; Sanz, J.; Amat-Guerri, F.; García, N. A Rose Bengal-sensitized photooxidation of the dipeptides L-tryptophyl-L-phenylalanine, L-tryptophyl-L-tyrosine and L-tryptophyl-L-tryptophan: Kinetics, mechanism and photoproducts. Photochem. Photobiol. 2004, 80, 132-138. [CrossRef]

8. Katritzky, A.R.; Haase, D.N.; Johnson, J.V.; Chung, A. Benzotriazole-assisted solid-phase assembly of Leu-enkephalin, amyloid beta segment 34-42, and other "difficult" peptide sequences. J. Org. Chem. 2009, 74, 2028-2032. [CrossRef]

9. Angell, Y.; Alsina, J.; Albericio, F.; Barany, G. Practical protocols for stepwise solid-phase synthesis of cysteine-containing peptides. J. Pept. Res. 2002, 60, 292-299. [CrossRef]

10. Angeletti, R.H.; Bibbs, L.; Bonewald, L.F.; Fields, G.B.; Kelly, J.W.; McMurray, J.S.; Moore, W.T.; Weintraub, S.T. 1997. Analysis of racemization during "standard" solid phase peptide synthesis: A multicenter study. In Techniques in Protein Chemistry VIII; Marshak, D.R., Ed.; Academic Press, Inc.: San Diego, CA, USA, 1997; pp. 875-890.

11. Han, Y.; Albericio, F.; Barany, G. Occurrence and Minimization of Cysteine Racemization during Stepwise Solid-Phase Peptide Synthesis. J. Org. Chem. 1997, 7, 4307-4312. [CrossRef]

12. Vommina, V.V.; Narendra, N. Protection Reactions. In Amino Acids, Peptides and Proteins in Organic Chemistry. In Protection Reactions, Medicinal Chemistry, Combinatorial Synthesis; Hughes, A.B., Ed.; Wiley-VCH Verlag GmbH \& Co.: Weinheim, Germany, 2011; Volume 4; pp. 1-97.

13. Yang, Y. Peptide Oxidation/Reduction Side Reactions. In Side Reactions in Peptide Synthesis; Elsevier Inc.: Amsterdam, The Netherlands, 2015; pp. 217-233.

14. Yang, H.; Zubarev, R. Mass spectrometric analysis of asparagine deamidation and aspartate isomerization in polypeptides. Electrophoresis 2010, 31, 1764-1772. [CrossRef] [PubMed]

15. Ouellette, D.; Chumsae, C.; Clabbers, A.; Radziejewski, C.; Correia, I. Comparison of the in vitro and in vivo stability of a succinimide intermediate observed on a therapeutic IgG1 molecule. $m A$ bs 2013, 5, 432-444. [CrossRef] [PubMed]

16. Zhang, J.; Yip, H.; Katta, V. Identification of isomerization and racemization of aspartate in the Asp-Asp motifs of a therapeutic protein. Anal. Biochem. 2011, 410, 234-243. [CrossRef]

17. Machado, Y.; Rabasa, Y.; Montesinos, R.; Cremata, J.; Besada, V.; Fuentes, D.; Castillo, A.; de la Luz, K.; Vázquez, A.; Himly, M. Physicochemical and biological characterization of 1E10 Anti-Idiotype vaccine. BMC Biotechnol. 2011, 11, 112.

18. Cacia, J.; Keck, R.; Presta, L.G.; Frenz, J. Isomerization of an aspartic acid residue in thecomplementarity-determining regions of a recombinant antibody to human IgE: Identification and effect on binding affinity. Biochemistry 1996, 35, 1897-1903. [CrossRef] [PubMed]

19. Xie, M.; Shahrokh, Z.; Kadkhodayan, M.; Henzel, W.J.; Powell, M.F.; Borchardt, R.T.; Schowen, R.L. Asparagine deamidation in recombinant human lymphotoxin: Hindrance by three-dimensional structures. J. Pharm. Sci. 2003, 92, 869-880. [CrossRef] [PubMed]

20. Stevenson, C.L.; Friedman, A.R.; Kubiak, T.M.; Donlan, M.E.; Borchardt, R.T. Effect of secondary structure on the rate of deamidation of several growth hormone releasing factor analogs. Int. J. Pept. Protein Res. 1993, 42, 497-503. [CrossRef]

21. Di Salvo, M.L.; Delle Fratte, S.; Maras, B.; Bossa, F.; Wright, H.T.; Schirch, V. Deamidation of asparagine residues in a recombinant serine hydroxy methyltransferase. Arch. Biochem. Biophys. 1999, 372, 271-279. [CrossRef]

22. Huang, L.; Lu, J.; Wroblewski, V.J.; Beals, J.M.; Riggin, R.M. In vivo deamidation characterization of monoclonal antibody by LC/MS/MS. Anal. Chem. 2005, 77, 1432-1439. [CrossRef]

23. Kerlero de Rosbo, N.; Milo, R.; Lees, M.B.; Burger, D.; Bernard, C.C.; Ben-Nun, A. Reactivity to myelin antigens in multiple sclerosis. Peripheral blood lymphocytes respond predominantly to myelin oligodendrocyte glycoprotein. J. Clin. Investig. 1993, 92, 2602-2608. [CrossRef] 
24. Linington, C.; Berger, T.; Perry, L.; Werth, S.; Hinze-Selch, D.; Zhang, Y.; Lu, H.C.; Lassmann, H.; Wekerle, H. $\mathrm{T}$ cells specific for the myelin oligodendrocyte glycoprotein mediate an unusual autoimmune inflammatory response in the central nervous system. Eur. J. Immunol. 1993, 23, 1364-1372. [CrossRef] [PubMed]

25. Amor, S.; Groome, N.; Linington, C.; Morris, M.M.; Dornmair, K.; Gardinier, M.V.; Matthieu, J.M.; Baker, D. Identification of epitopes of myelin oligodendrocyte glycoprotein for the induction of experimental allergic encephalomyelitis in SJL and Biozzi AB/H mice. J. Immunol. 1994, 153, 4349-4356. [PubMed]

26. Ichikawa, M.; Johns, T.G.; Liu, J.; Bernard, C.C. Analysis of the fine B cell specificity during the chronic/relapsing course of a multiple sclerosis-like disease in Lewis rats injected with the encephalitogenic myelin oligodendrocyte glycoprotein peptide 35-55. J. Immunol. 1996, 157, 919-926. [PubMed]

27. Constantinescu, C.S.; Farooqi, N.; O’Brien, K.; Gran, B. Experimental autoimmune encephalomyelitis (EAE) as a model for multiple sclerosis (MS). Br. J. Pharmacol. 2011, 164, 1079-1106. [CrossRef] [PubMed]

28. Bittner, S.; Afzali, A.M.; Wiendl, H.; Meuth, S.G. Myelin oligodendrocyte glycoprotein (MOG35-55) induced experimental autoimmune encephalomyelitis (EAE) in C57BL/6 mice. J. Vis. Exp. 2014, 86, e51275.

29. Stromnes, I.M.; Goverman, J.M. Active induction of experimental allergic encephalomyelitis. Nat. Protoc. 2006, 1, 1810-1819. [CrossRef]

30. Tselios, T.; Aggelidakis, M.; Tapeinou, A.; Tseveleki, V.; Kanistras, I.; Gatos, D.; Matsoukas, J. Rational design and synthesis of altered peptide ligands based on Human myelin oligodendrocyte glycoprotein 35-55 epitope: Inhibition of chronic experimental autoimmune encephalomyelitis in mice. Molecules 2014, 19, 17968-17984. [CrossRef]

31. Tseveleki, V.; Tselios, T.; Kanistras, I.; Koutsoni, O.; Karamita, M.; Vamvakas, S.S.; Apostolopoulos, V.; Dotsika, E.; Matsoukas, J.; Lassmann, H.; et al. Mannan-conjugated myelin peptides prime non-pathogenic Th1 and Th17 cells and ameliorate experimental autoimmune encephalomyelitis. Exp. Neurol. 2014, 267, 254-267. [CrossRef]

32. Tapeinou, A.; Matsoukas, M.T.; Simal, C.; Tselios, T. Review cyclic peptides on a merry-go-round; towards drug design. Biopolymers 2015, 104, 453-461. [CrossRef]

33. Day, S.; Tselios, T.; Androutsou, M.E.; Tapeinou, A.; Frilligou, I.; Stojanovska, L.; Matsoukas, J.; Apostolopoulos, V. Mannosylated Linear and Cyclic Single Amino Acid Mutant Peptides Using a Small 10 Amino Acid Linker Constitute Promising Candidates Against Multiple Sclerosis. Front. Immunol. 2015, 6, 136. [CrossRef]

34. Tapeinou, A.; Androutsou, M.E.; Kyrtata, K.; Vlamis-Gardikas, A.; Apostolopoulos, V.; Matsoukas, J.; Tselios, T. Conjugation of a peptide to mannan and its confirmation by tricine sodium dodecyl sulfate-polyacrylamide gel electrophoresis. Anal. Biochem. 2015, 485, 43-45. [CrossRef] [PubMed]

35. Tapeinou, A.; Giannopoulou, E.; Simal, C.; Hansen, B.E.; Kalofonos, H.; Apostolopoulos, V.; Vlamis-Gardikas, A.; Tselios, T. Design, synthesis and evaluation of an anthraquinone derivative conjugated to myelin basic protein immunodominant (MBP85-99) epitope: Towards selective immunosuppression. Eur. J. Med. Chem. 2018, 143, 621-631. [CrossRef] [PubMed]

36. Androutsou, M.E.; Tapeinou, A.; Vlamis-Gardikas, A.; Tselios, T. Myelin Oligodendrocyte Glycoprotein and Multiple Sclerosis. Med. Chem. 2018, 14, 120-128. [CrossRef] [PubMed]

37. Yannakakis, M.P.; Simal, C.; Tzoupis, H.; Rodi, M.; Dargahi, N.; Prakash, M.; Mouzaki, A.; Platts, J.A.; Apostolopoulos, V.; Tselios, T. Design and Synthesis of Non-Peptide Mimetics Mapping the Immunodominant Myelin Basic Protein (MBP83-96) Epitope to Function as T-Cell Receptor Antagonists. Int. J. Mol. Sci. 2017, 18, 1215. [CrossRef] [PubMed]

38. Lutterotti, A.; Yousef, S.; Sputtek, A.; Stürner, K.; Stellmann, J.P.; Breiden, P.; Reinhardt, S.; Schulze, C.; Bester, M.; Heesen, C.; et al. Antigen-Specific Tolerance by Autologous Myelin Peptide-Coupled Cells: A Phase 1 Trial in Multiple Sclerosis. Sci. Transl. Med. 2013, 5, 188ra75. [CrossRef]

39. Emmanouil, M.; Tseveleki, V.; Triantafyllakou, I.; Nteli, A.; Tselios, T.; Probert, L. A Cyclic Altered Peptide Analogue Based on Myelin Basic Protein 87-99 Provides Lasting Prophylactic and Therapeutic Protection Against Acute Experimental Autoimmune Encephalomyelitis. Molecules 2018, 2, 304. [CrossRef]

40. Tselios, T.; Daliani, I.; Deraos, S.; Thymianou, S.; Matsoukas, E.; Troganis, A.; Gerothanassis, I.; Mouzaki, A.; Mavromoustakos, T.; Probert, L.; et al. Treatment of experimental allergic encephalomyelitis (eae) by a rationally designed cyclic analogue of myelin basic protein (mbp) epitope 72-85. Bioorg. Med. Chem. Lett. 2000, 10, 2713-2717. [CrossRef] 
41. Tselios, T.; Apostolopoulos, V.; Daliani, I.; Deraos, S.; Grdadolnik, S.; Mavromoustakos, T.; Melachrinou, M.; Thymianou, S.; Probert, L.; Mouzaki, A.; et al. Antagonistic effects of human cyclic MBP(87-99) altered peptide ligands in experimental allergic encephalomyelitis and human t-cell proliferation. J. Med. Chem. 2002, 45, 275-283. [CrossRef]

42. Matsoukas, J.; Apostolopoulos, V.; Kalbacher, H.; Papini, A.M.; Tselios, T.; Chatzantoni, K.; Biagioli, T.; Lolli, F.; Deraos, S.; Papathanassopoulos, P.; et al. Design and synthesis of a novel potent myelin basic protein epitope 87-99 cyclic analogue: Enhanced stability and biological properties of mimics render them a potentially new class of immunomodulators. J. Med. Chem. 2005, 48, 1470-1480. [CrossRef]

43. Mantzourani, E.D.; Platts, J.A.; Brancale, A.; Mavromoustakos, T.M.; Tselios, T.V. Molecular dynamics at the receptor level of immunodominant myelin basic protein epitope 87-99 implicated in multiple sclerosis and its antagonists altered peptide ligands: Triggering of immune response. J. Mol. Graph. Model. 2007, 26, 471-481. [CrossRef]

44. Mantzourani, E.D.; Mavromoustakos, T.M.; Platts, J.A.; Matsoukas, J.M.; Tselios, T.V. Structural requirements for binding of myelin basic protein (mbp) peptides to mhc ii: Effects on immune regulation. Curr. Med. Chem. 2005, 12, 1521-1535. [CrossRef] [PubMed]

45. Friligou, I.; Rizzolo, F.; Nuti, F.; Tselios, T.; Evangelidou, M.; Emmanouil, M.; Karamita, M.; Matsoukas, J.; Chelli, M.; Rovero, P.; et al. Divergent and convergent synthesis of polymannosylated dibranched antigenic peptide of the immunodominant epitope mbp(83-99). Bioorg. Med. Chem. 2013, 21, 6718-6725. [CrossRef] [PubMed]

46. Ieronymaki, M.; Androutsou, M.E.; Pantelia, A.; Friligou, I.; Crisp, M.; High, K.; Penkman, K.; Gatos, D.; Tselios, T. Use of the 2-chlorotrityl chloride resin for microwave-assisted solid phase peptide synthesis. Biopolymers 2015, 104, 506-514. [CrossRef] [PubMed]

47. Dagkonaki, A.; Avloniti, M.; Evangelidou, M.; Papazian, I.; Kanistras, I.; Tseveleki, V.; Lampros, F.; Tselios, T.; Jensen, L.T.; Möbius, W.; et al. Mannan-MOG $35-55$ reverses experimental autoimmune encephalomyelitis, inducing a peripheral type 2 myeloid response, reducing CNS inflammation and preserving axons in spinal cord lesions. Front. Immunol. 2020, accepted for publication.

48. Mendel, I.; de Rosbo, N.K.; Ben-Nun, A. A myelin oligodendrocyte glycoprotein peptide induces typical chronic experimental autoimmune encephalomyelitis in $\mathrm{H}-2 \mathrm{~b}$ mice: Fine specificity and $\mathrm{T}$ cell receptor $\mathrm{V}$ beta expression of encephalitogenic T cells. Eur. J. Immunol. 2015, 25, 1951-1959. [CrossRef]

Publisher's Note: MDPI stays neutral with regard to jurisdictional claims in published maps and institutional affiliations.

(C) 2020 by the authors. Licensee MDPI, Basel, Switzerland. This article is an open access article distributed under the terms and conditions of the Creative Commons Attribution (CC BY) license (http://creativecommons.org/licenses/by/4.0/). 